Available online at:http://jtb.ulm.ac.id/index.php/JTB

Volume 7 Nomor 1

ISSN: 2302-8394 (print)

\title{
ANALISIS DAYA DUKUNG TIANG GROUP PADA TANAH BERLENSA DI KOTA BANJARMASIN DENGAN PLAXIS 2D
}

\author{
Yayuk Setiyowati ${ }^{1}$, Yulian Firmana Arifin ${ }^{2}$ \\ ${ }^{1}$ Program Studi Magister Teknik Sipil Universitas Lambung Mangkurat \\ ${ }^{2}$ Faculty of Engineering, Lambung Mangkurat University
}

\begin{abstract}
ABSTRAK
Lapisan lensa pasir memiliki karakteristik kuat geser yang lebih besar jika dibandingkan dengan lapisan tanah di atas maupun di bawahnya. Hal ini lah yang menyebabkan lapisan ini seringkali dikira sebagai lapisan tanah keras diakibatkan pembacaan dari hasil sondir menunjukkan nilai tahanan ujung yang hampir mendekati dengan nilai tahanan ujung lapisan tanah keras. Memiliki nilai c yang hampir sama dengan lapisan tanah keras membawa peneliti berasumsi bahwa lapisan ini sebenarnya memiliki potensi untuk dijadikan sebagai lapisan penahan pondasi untuk group tiang. Penelitian ini merupakan penelitian dengan skala kecil dengan membuat model group tiang dalam finite element dengan variabel pengaruh ketebalan lensa pasir $\left(t_{\text {lensa pasir }}\right)$, diameter tiang $\left(B_{\text {tiang }}\right)$, dan jarak tiang $\left(S_{\text {tiang }}\right)$ terhadap daya dukung. Permodelan lapisan tanah berlensa pasir dianalisa dengan menggunakan permodelan linear elastis yang terdapat di dalam program Plaxis. Data Tanah Permodelan diambil dari data tanah proyek flyover Gatot Subroto Banjarmasin. Kemudian permodelan group tiang dibuat dengan memodelkan baris plane dari tiang disederhanakan sebagai wall elements atau disebut plane strain tiang. Wall element didefinisikan per meter; kekakuan normal, kekakuan lentur dan berat dari tiang di luar baris plane dari tiang adalah dianggap per meter. Untuk mengekivalensikan wall element kedalaman kondisi yang sebenarnya di lapangan dimana group tiang berbaris kebelakang, maka digunakan rumus ekivalen terhadap kekakuan seperti yang dipaparkan oleh Andre Rytenius dalam master disertasinya. Pada tesis ini, daya dukung pondasi tiang tunggal dianalisis menggunakan metode Meyerhof dan Hanna's. Hasil perhitungan daya dukung ultimit pondasi tiang tunggal $(40 \mathrm{~m})$ berdasarkan perhitungan manual diperoleh hasil sebesar 10438,1477 kN/m2. Dengan Plaxis, daya dukung yang didapat adalah $9000 \mathrm{kN} / \mathrm{m} 2$. Daya dukung tiang tunggal pada lapisan lensa hasil PLAXIS lebih kecil dari hasil perhitungan daya dukung secara teoritis. Daya dukung kelompok tiang pada lapisan lensa hasil PLAXIS didapatkan untuk diameter yang sama didapatkan kenaikan daya dukung berbanding lurus dengan kenaikan ketebalan lensa pasir. Kenaikan daya dukung tersebut dikarenakan karakteristik kuat geser dari lapisan lensa pasir yang memberikan pengaruh besar dan bahwa lensa yang memiliki tebal lebih dari 4 meter sudah memiliki karakteristik seperti tanah keras. Sedangkan untuk ketebalan lensa pasir yang sama maka didapatkan penurunan daya dukung berbanding lurus dengan kenaikan diameter tiang. Penurunan daya dukung tersebut dikarenakan area tekan pada lapisan lensa pasir memberikan pengaruh yang signifikan. Pada konfigurasi 4 tiang, jarak antar tiang yang paling berperan dalam memberikan daya dukung adalah di jarak antar tiang 3D, dimana hasil daya dukung yang dihasilkan pada jarak ini lebih tinggi. Sedangkan hasil daya dukung pada jarak antar tiang 4D dan 5D mengalami penurunan, dimungkinkan karena cara penarikan garis pada grafik daya dukung dengan penurunan. Pada konfigurasi 9 tiang, hasil didapatkan hampir serupa dengan hasil yang didapatkan pada konfigurasi 4 tiang. Dimana jarak antar tiang yang paling berperan dalam memberikan daya dukung adalah di jarak antar tiang 3D dan 5D, dimana hasil daya dukung yang dihasilkan pada jarak ini lebih tinggi.Sedangkan hasil daya dukung pada jarak antar tiang 4D mengalami penurunan, dimungkinkan karena cara penarikan garis pada grafik daya dukung dengan penurunan. Konfigurasi tiang yang lebih baik untuk diterapkan pada tanah berlensa pasir adalah konfigurasi 4 tiang simetris, dimana hasil daya dukung yang dihasilkan pada konfigurasi ini lebih tinggi dibandingkan konfigurasi 9 tiang simetris.
\end{abstract}

Kata Kunci : lensa pasir, group tiang, tebal lensa, diameter tiang, jarak tiang

\section{PENDAHULUAN}

Kota Banjarmasin berdasarkan Peta Geologi Kalimantan (1994) merupakan salahsatu daerah di Provinsi Kalimantan Selatan yang memiliki karakteristik tanah Correspondence: Yayuk Setiyowati

Email:yayuksetiyowati@ymail.com berupa lapisan aluvial. Lapisan aluvial adalah lapisan yang terbentuk akibat adanya angkutan sedimen dari aliran air yang kemudian menumpuk dan mengendap di bagian yang lebih rendah selama prosesnya. Lapisan aluvial umumnya terdiri dari lapisan kerikil, pasir, lanau, lempung dan lumpur. Lapisan demi lapisan yang terbentuk akibat endapan 
Yayuk Setiyowati dan Yulian Firmana Arifin

sedimen yang terjadi memungkinkan terbentuknya suatu lapisan relatif tipis dan luas yang memiliki karakteristik seperti tanah keras. Lapisan seperti ini-lah yang kemudian disebut sebagai "lensa pasir". Lapisan lensa pasir memiliki karakteristik kuat geser yang lebih besar jika dibandingkan dengan lapisan tanah di atas maupun di bawahnya. Hal ini lah yang menyebabkan lapisan ini seringkali dikira sebagai lapisan tanah keras diakibatkan pembacaan dari hasil sondir menunjukkan nilai tahanan ujung yang hampir mendekati dengan nilai tahanan ujung lapisan tanah keras. Memiliki nilai c yang hampir sama dengan lapisan tanah keras membawa peneliti berasumsi bahwa lapisan ini sebenarnya memiliki potensi untuk dijadikan sebagai lapisan penahan pondasi untuk group tiang. Seberapa efektifnya lapisan ini sebagai penahan pondasi group tiang adalah tujuan dari penelitian ini. Beberapa konstruksi di Kota Banjarmasin yang terindikasi terkena lapisan ini salah satunya adalah Proyek Pembangunan Jembatan Kelayan dan Proyek Pembangunan FlyOver Gatot Subroto Banjarmasin. Dari hasil tes sondir pada Jembatan Kelayan didapatkan lapisan tanah keras berada dikedalaman 40 meter. Namun ketika dilakukan pemancangan tiang yang ke-n kali, kedalaman pancang tiang melebihi kedalaman pancang tiang rencana yang didasarkan pada hasil test sondir. Hal ini kemungkinan dikarenakan pada saat pemancangan tiang, lapisan lensa pasir yang dianggap sebagai lapisan tanah keras tersebut pecah. Sehingga pada akhirnya semua tiang dipancang sampai kedalaman 58 meter, yaitu kedalaman tanah keras yang sebenarnya berada. Pada FO GatSu Banjarmasin pondasi terpasang saat ini adalah $60 \mathrm{~m}$. Padahal ada beberapa lapisan tanah keras pada kedalaman $40 \mathrm{~m}$, hanya saja di bawahnya terdapat lapisan lempung dengan NSPT lebih kecil. Lapisan lensa pasir tanah umumnya karena memiliki karakteristik lensa pasir dalam artian tipis maka memiliki tebal berkisar 1 sampai dengan 4 meter adapun pada FO GatSu Banjarmasin lensa pasir pasir memiliki ketebalan sampai dengan 8 meter. Lapisan lensa pasir tanah ini dapat bersifat setempat (lokal) maupun meluas. Kedalaman lapisan lensa pasir tidak dapat dipastikan, karena sangat beragam. Pemastian ketebalan lensa pasir untuk lebih akurat dapat dilakukan dengan boring log pada titik titik rencana pondasi yang akan dikerjakan.

Tomlinson (2004) juga mengatakan bahwa pondasi tiang yang menggunakan lapisan lensa pasir yang berada di atas lapisan lempung lunak yang kompressibel sebagai lapisan tahanan ujung tiang sebelumnya mendapatkan hasil yang diharapkan ketika loading test dengan single tiang. Akan tetapi, setelah group tiang diterapkan, zona tekanan meluas sampai akhirnya mencapai lapisan lempung lunak yang berada di bagian bawah lensa pasir. Sehingga kegagalan geser terjadi. Dari pemaparan ini maka dapat ditarik suatu asumsi, kondisi lensa pasir tanah yang bagaimanakah yang dapat memberikan tahanan yang cukup dalam menahan beban dari group tiang. Sampai saat ini, analisa daya dukung pondasi di atas lensa pasir belum dijelaskan di literatur, untuk mempermudah dan membantu analisa digunakan program Fenite Element (PLAXIS). Kondisi di lapangan yang disimulasikan ke dalam program Plaxis ini bertujuan untuk mengimplementasikan tahapan pelaksanaan di lapangan ke dalam tahapan pengerjaan pada program, dengan harapan pelaksanaan di lapangan dapat didekati sedekat mungkin pada program, sehingga respon yang dihasilkan dari program dapat diasumsikan sebagai cerminan dari kondisi yang sebenarnya terjadi di lapangan. Penelitian menggunakan PLAXIS 2D, akan memberikan gambaran sejauh mana lapisan lensa pasir tanah dapat memberikan daya dukung dalam menahan beban tiang group. Penelitian ini merupakan penelitian dengan skala kecil dengan membuat model group tiang dalam finite element dengan variabel pengaruh ketebalan lensa pasir ( $t_{\text {lensa }}$ pasir), diameter tiang $\left(\mathrm{B}_{\text {tiang }}\right)$, dan jarak tiang $\left(\mathrm{S}_{\text {tiang }}\right)$ terhadap daya dukung sehingga didapatkan jawaban sejauh mana lapisan lensa pasir tanah dalam memberikan daya dukung. Diharapkan hasil dari penelitian ini dapat digunakan sebagai rujukan untuk penggunaan pondasi group tiang di Banjarmasin.

\section{METODE PENELITIAN}

Adapun tahapan yang dilakukan pada penelitian ini dapat dilihat pada Gambar 1 . 


\section{Tahap Penelitian}

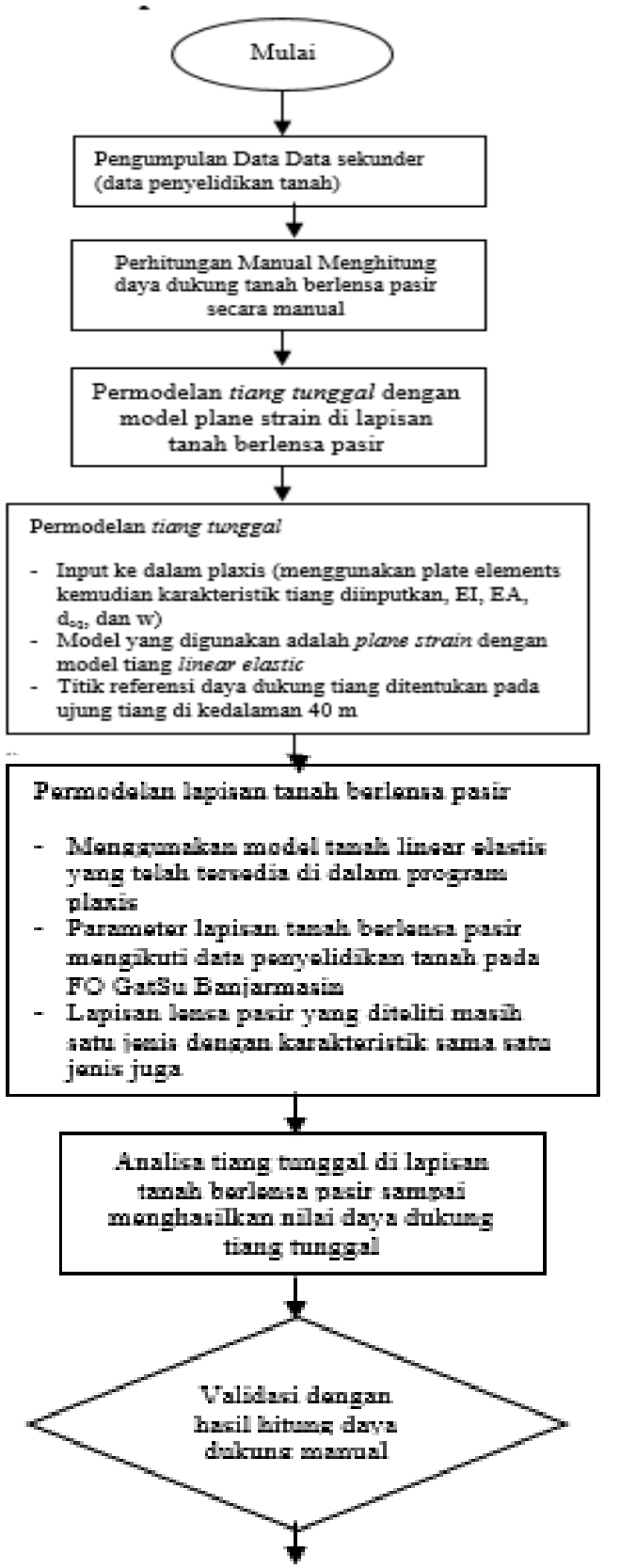

Permodalan tiant keliempolk

- Input ke dalam plaxis (mengrumakan plate elements

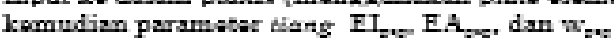
diimputisan)

- Model yang diganakm adalah plarte jurair dengan molakukan akivalensi kakakusn tiang dengan rumas dari Andre Ryisentus

- Jumlah tiang (a) yamg digunzian adalah 4 tiang dan

9 tiana denzan posisi letak yang simetris

- Dismatar tiang yang digunakam adalah 300; 400; 500, dan $600 \mathrm{~mm}$

- Jarak antar tieng yang digunakan adalah 2D; 3D. 4D, 5D.

- Pambebanan sampai batas keruntuhan lapisan lensa Dasir

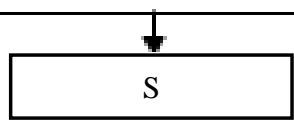

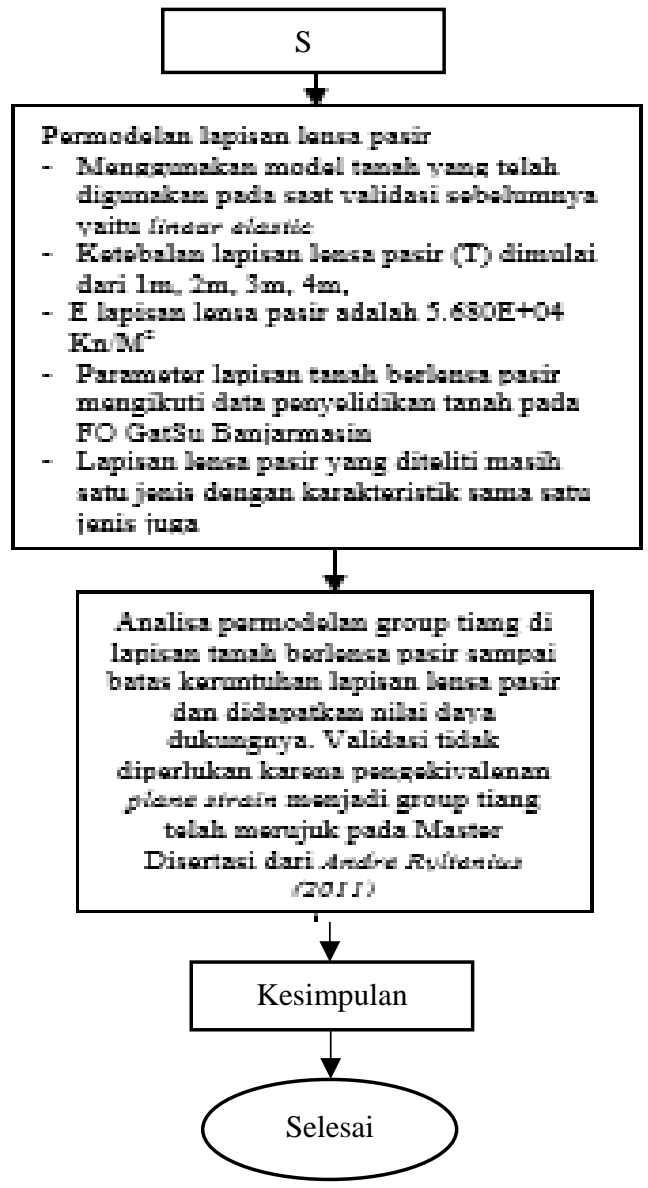

Gambar 3.1 Lanjutan

\subsection{Perancangan Model}

Penelitian dilakukan dengan menggunakan bantuan program Plaxis 2D. Pelaksanaan penelitian dimulai dengan mempersiapkan data terlebih dahulu.

\subsubsection{Pengumpulan Data}

Terdiri dari data sekunder yang didapat dari proyek flyover Gatot Subroto Banjarmasin. Dari data penyelidikan tanah diperoleh parameter tanah berupa berat volume $(\gamma)$ baik gamma saturated maupun gamma unsaturated, permeabiliti baik arah $\mathrm{x}$ $\left(\mathrm{k}_{\mathrm{x}}\right)$ dan arah $\mathrm{y}\left(\mathrm{k}_{\mathrm{y}}\right)$, modulus young $(\mathrm{E})$ dan poisson's ratio $(\mathrm{v})$, cohesi $(c)$, sudut gesek dalam $(\phi)$. Kemudian data tersebut diinput pada program Plaxis.

Gambar 3.1 Bagan Alir Metode Penelitian pada Program Plaxis 
Yayuk Setiyowati dan Yulian Firmana Arifin

\subsubsection{Permodelan Tiang tunggal}

Permodelan tiang tunggal dianalisa dengan model plane strain, Dari segi pembebanan tiang tunggal yang dimana beban yang akan dimasukan ke dalam program plaxis setiap kenaikan $1000 \mathrm{kN}$. Input ke dalam plaxis (menggunakan plate elements, kemudian parameter tiang berupa EI, EA, $\mathrm{d}_{\mathrm{eq}}$, dan $\mathrm{W}$ diinputkan) dengan menggunakan model tiang elastic linear. Titik referensi daya dukung tiang ditentukan pada ujung tiang di kedalaman $40 \mathrm{~m}$. Untuk penggambaran geometri tiang tunggal seperti yang terlihat pada Gambar 1.

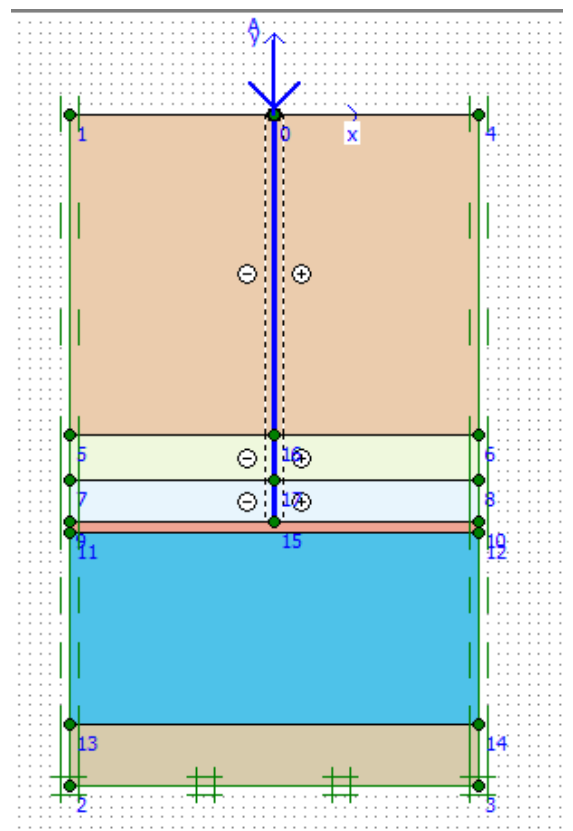

Gambar 1. Permodelan Model plane strain Tiang tunggal pada tanah berlensa

\subsection{Permodelan Lapisan Tanah Berlensa pasir}

Permodelan lapisan tanah berlensa pasir dianalisa dengan menggunakan permodelan linear elastis yang terdapat di dalam program Plaxis. Data Tanah Permodelan diambil dari data tanah proyek flyover Gatot Subroto Banjarmasin.

\subsection{Permodelan Tiang kelompok}

Kemudian permodelan group tiang dibuat dengan memodelkan baris plane dari tiang disederhanakan sebagai wall elements atau disebut plane strain tiang.
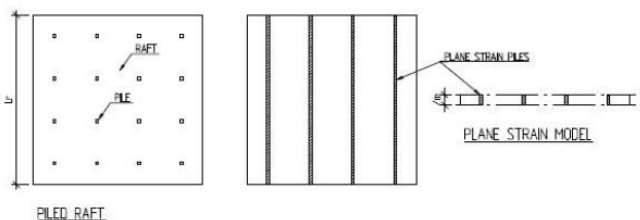

Gambar 2. Plane Strain model untuk pondasi (Andre Ryltenius, 2011)

Wall element didefinisikan per meter; kekakuan normal, kekakuan lentur dan berat dari tiang di luar baris plane dari tiang adalah dianggap per meter, dimana:

$E A_{p s p}=E A_{p} \frac{n_{p-r o w-i}}{L_{r}}$

$\mathrm{EA}_{\mathrm{psp}}=$ Kekakuan normal untuk plane strain pile

$\mathrm{EA}_{\mathrm{p}}=$ Kekakuan normal untuk satu tiang

$\mathrm{n}_{\mathrm{p}-\mathrm{row}-\mathrm{i}}=$ Jumlah tiang dalam baris $\mathrm{i}$

$\mathrm{L}_{\mathrm{r}}=$ Panjang Rakit dalam plane

Kekakuan lentur didapatkan dari persamaan berikut:

$E I_{p s p}=E I_{p} \frac{n_{p-r o w-i}}{L_{r}}$

Berat dari tiang didapatkan dari persamaan berikut:

$w_{p s p}=w_{p} \frac{n_{p-r o w-i}}{L_{r}}$

Di dalam Plaxis, plane strain tiang dimodelkan dengan menggunakan plate elements dengan adanya interface elements dimana interface element digambarkan sebagai interaksi antara tiang dengan tanah. Bagaimanapun, interface element memiliki properties kekuatan disekitar tanah yang berkali lipat yang disebut sebagai faktor $\mathrm{R}_{\text {inter }}$ ( faktor reduksi kekuatan untuk interface ).

$R_{\text {inter }, e q}=\propto_{\text {ar }} R_{\text {inter }}=\frac{n_{p-\text { row }-i} A_{s}}{2 L_{r}}$

Dimana permodelan tiang kelompok seperti yang terlihat pada Gambar 3.

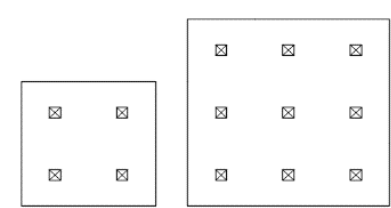

Gambar 3. Permodelan Tiang kelompok 


\subsection{Implementasi Model}

Diawali dengan permodelan tiang tunggal. Setelah dilakukan permodelan selanjutnya ditentukan kondisi batas. Kondisi batas dilakukan untuk menghindari perpindahan geometri yang tidak dapat dipastikan. Selanjutnya dilakukan input properties plate elements dan parameter material tanah. Untuk lapisan tanah berlensa pasir akan dimasukan parameter tanah sesuai dengan data penyelidikan tanah yang ada. Dan untuk tiang tunggal akan dimodelkan menggunakan plate element dengan material beton. Kemudian untuk pembebanan dilakukan beban setiap $1000 \mathrm{kN}$. Apabila permodelan input selesai, maka dapat dihasilkan model elemen hingga pada mesh generation. Dimana Plaxis secara otomatis mentransformasikan input data ke dalam mesh elemen hingga yang dihasilkan. Sebelum masuk ke tahap perhitungan, initial condition (kondisi awal) harus dihasilkan dengan memasukan nilai berat jenis air yaitu 10 $\mathrm{KN} / \mathrm{m}^{3}$. Kemudian phereatic level digambarkan pada elevasi $0 \mathrm{~m}$ (di atas permukaan tanah), karena menganggap tanah Banjarmasin dalam kondisi jenuh. Closed consolidation boundary juga digambarkan pada sisi kiri dan kanan geometri agar air tidak mengalir ke luar ataupun ke dalam kondisi boundary. Setelah itu tekanan air pori dapat dihasilkan dengan masuk kepada initial pore pressure-initial stress and geometry configuration. Kemudian dilakukan tahap perhitungan. Pada perhitungan dilakukan beberapa tahap dengan analisis plastis dan konsolidasi. Selanjutnya dapat dihasilkan output program berupa deformasi mesh dan vertical displacement.

\subsection{Validasi dan Verifikasi Model}

Validasi permodelan tiang tunggal dilakukan dengan membandingkan daya dukung yang dihasilkan dari Plaxis pada permodelan tiang tunggal dengan hasil perhitungan secara manual menggunakan rumus daya dukung pada kondisi tanah berlapis. Dan apabila didapatkan hasil yang mendekati maka disimpulkan bahwa permodelan yang dibuat sudah sesuai dengan kondisi asli maka permodelan dapat mulai diimplementasikan kedalam kasus tiang kelompok dengan variabel penelitian seperti yang dijabarkan pada bagan alir pada Gambar 3.1. Validasi dari group tiang dari plane strain menerus menjadi group tiang berbaris penulis simpulkan tidak diperlukan karena validasi tersebut telah dilakukan oleh Andre Ryltenius (2011) dalam Master Disertasinya

\section{PEMBAHASAN}

\subsection{Daya Dukung Tiang Tunggal Pada Tanah Berlapis}

\subsubsection{Cara Manual}

Dalam perhitungan daya dukung pondasi, kondisi tanah dianggap homogen yang mana nilai kohesi, sudut gesek dalam, dan berat jenis tanah diasumsikan konstan. Akan tetapi pada kenyataannya, sering sekali didapati bahwa tanah terdiri lebih dari satu jenis kondisi tanah dalam artian kondisi tanah non homegen. Untuk mengestimasi kapasitas daya dukung pada tanah yang berlapis telah dilakukan oleh, Mayerhof dan Hanna (1978) dan Mayerhof (1974). Kapasitas daya dukung pondasi pada tanah berlapis juga telah diuraikan oleh Braja (1995), seperti terlihat pada Gambar 4. Di dalam penelitian ini, dari 3 macam kasus dalam pehitungan daya dukung pondasi pada tanah belapis yang sesuai adalah kasus 1 dimana lapisan atas adalah pasir padat dan lapisan bawah adalah lempung lunak jenuh $\left(\mathrm{B}_{2}=0\right)$.

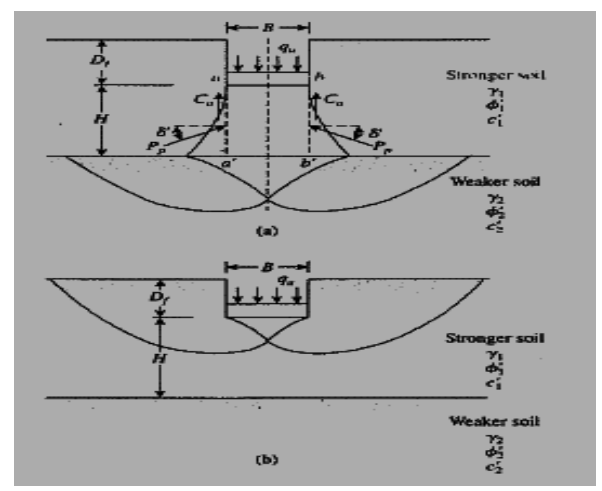

Gambar 4. Kapasitas daya dukung pondasi pada tanah berlapis (Braja, 1995)

Kasus 1. Lapisan atas adalah pasir padat dan lapisan bawah adalah lempung lunak jenuh $\left(B_{2}=0\right)$.

Kapasitas daya dukung diberikan dalam persamaan di bawah ini, 


$$
\begin{aligned}
q_{n}=\left(1+0,2 \frac{B}{L}\right) 5,14 c_{2} \\
+\gamma_{1} H^{2}\left(1+\frac{B}{L}\right)(1 \\
\left.+\frac{2 D_{f}}{H}\right) \frac{K_{s} \tan \emptyset^{\prime}}{B}+\gamma_{1} D_{f}
\end{aligned}
$$$$
\leq \gamma_{1} D_{f} N_{q(1)} F_{q S(1)}+\frac{1}{2} \gamma_{1} B N_{\gamma(1)} F_{\gamma S(1)}
$$

Dimana, $\mathrm{c}_{2}=$ kohesi dalam kondiri undrained,

Untuk menentukan besaran nilai dari $\mathrm{K}_{\mathrm{s}}$ didapat dari Gambar 2.7.

$$
\frac{q_{2}}{q_{1}}=\frac{c_{2} N_{c(2)}}{\frac{1}{2} \gamma_{1} B N_{\gamma(1)}}=\frac{5,14 c_{2}}{0,5 \gamma_{1} B N_{\gamma(1)}} \ldots \ldots \ldots \ldots . . .
$$
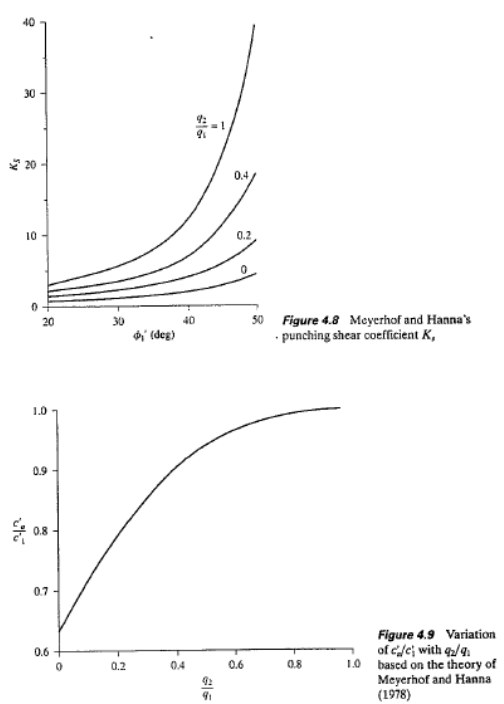

Gambar 5. Grafik menentukan nilai $\mathrm{K}_{\mathrm{s}}$ (Braja, 1995)

Perhitungan kapasitas daya dukung tiang tunggal per lapisan dari data laboratorium penyelidikan tanah.

Data yang diperlukan :

Lebar tiang $(\mathrm{B})=0,5 \mathrm{~m}$

Panjang tiang arah memanjang $(\mathrm{L})=0,5 \mathrm{~m}$

Keliling tiang $(\mathrm{m})=2 \mathrm{~m}$

Gamma tanah lapisan lensa pasir $\left(\gamma_{1}\right)=20,41$

$\mathrm{kn} / \mathrm{m} 3$

Tebal lapisan lensa pasir $(\mathrm{H})=1 \mathrm{~m}$

Dalam tiang tertanam $\mathrm{D}_{\mathrm{f}}=40 \mathrm{~m}$

Koefisien punching $\left(\mathrm{K}_{\mathrm{s}}\right)=$

$\frac{q_{2}}{q_{1}}=\frac{5,14 c_{2}}{0,5 \gamma_{1} B N_{\gamma_{(1)}}}$

Sudut gesek lapisan lensa pasir $\left(\mathrm{B}^{\prime}{ }_{1}\right)=36^{\circ}$

Kohesi lapisan di bawah lensa pasir $\left(\mathrm{c}_{2}\right)=$ $16 \mathrm{kN} / \mathrm{m}^{2}$

\subsubsection{Daya Dukung Ujung Tiang}

Perhitungan:

$$
\begin{aligned}
\frac{q_{2}}{q_{1}} & =\frac{5,14 c_{2}}{0,5 \gamma_{1} B N_{\gamma_{(1)}}} \\
\frac{q_{2}}{q_{1}} & =\frac{5,14 \times 16}{0,5 \times 20,14 \times 0,5 \times 56,31}=0,2862
\end{aligned}
$$

Berdasarkan Gambar 5 Grafik menentukan nilai $\mathrm{K}_{\mathrm{s}}$ maka didapatkan nilai $\mathrm{K}_{\mathrm{s}}$ sebesar 4

$$
\begin{aligned}
& q_{n}=\left(1+0,2 \frac{B}{L}\right) 5,14 c_{2} \\
&+\gamma_{1} H^{2}\left(1+\frac{B}{L}\right)(1 \\
&\left.+\frac{2 D_{f}}{H}\right) \frac{K_{s} \tan \emptyset_{1}^{\prime}}{B}+\gamma_{1} D_{f} \\
& q_{n}=\left(1+0,2 \frac{0,5}{L 0,5}\right) 5,14 \times 16+10,41 \\
& \times 1^{2}\left(1+\frac{0,5}{0,5}\right)(1 \\
&\left.+\frac{2 \times 40}{1}\right) \frac{4 \times \tan 36^{\circ}}{0,5} \\
&+10,41 \times 40 \\
& q_{n}=10438,1477 \mathrm{kn} / \mathrm{m}^{2} \\
& \leq \gamma_{1} D_{f} N_{q(1)} F_{q s(1)}+\frac{1}{2} \gamma_{1} B N_{\gamma(1)} F_{\gamma s(1)} \\
& \leq 10,41 \times 40 \times 37,75+\frac{1}{2} 10,41 \times 0,5 \\
& \times 56,31
\end{aligned}
$$

$\leq 15733,1775 \mathrm{kn} / \mathrm{m}^{2}$

$q_{n}=\quad 10438,1477$

$15733,1775 \mathrm{kn} / \mathrm{m}^{2}$

\subsubsection{Daya Dukung Selimut Tiang}

Nilai tahanan satuan skin friction pada tanah kohesif adalah:

$$
\begin{aligned}
& \mathrm{f}=\alpha i^{*} \cdot \mathrm{Cu}=0,55 \times 0,5 \mathrm{ton} / \mathrm{m}^{2}=0,275 \mathrm{ton} / \mathrm{m}^{2} \\
& \begin{aligned}
\mathrm{Qs}=\mathrm{f} . \mathrm{Li} \cdot \mathrm{p} & =0,275 \text { ton } / \mathrm{m}^{2} \times 40 \mathrm{~m} \times 2 \mathrm{~m} \\
& =22 \text { ton }
\end{aligned}
\end{aligned}
$$

Dari perhitungan kapasitas daya dukung ultimit tiang tunggal pada tanah berlensa pasir pada kedalaman $40 \mathrm{~m}$ adalah sebesar $10438,1477 \mathrm{kn} / \mathrm{m}^{2}$.

\subsubsection{Cara Numerik}

Pertama yang diperlukan adalah mengumpulkan parameter yang diperlukan oleh program, kemudian parameter tanah dan tiang di input ke dalam program Plaxis 2D. 
Yayuk Setiyowati dan Yulian Firmana Arifin

Parameter tiang yang diperlukan :

Lebar tiang $(B)=0,5 \mathrm{~m}$

Luas tiang $(\mathrm{A})=B \times B=0,25 \mathrm{~m}^{2}$

Inersia tiang $(\mathrm{I})=\frac{1}{12} \times b \times h^{3}=0,00213 \mathrm{~m}^{4}$

$\mathrm{K}$ tiang $(\mathrm{K})=400 \mathrm{MPa}=33,2 f^{\prime} c$

$\mathrm{E}$ tiang $(\mathrm{m})=4700 \times \sqrt{f c^{\prime}} \times 1000=$ $27081137,347 \mathrm{kN} / \mathrm{m}^{2}$

EA tiang $=\mathrm{E}$ tiang $\mathrm{x}$ Luas tiang $(\mathrm{A})=$ $6770284,337 \mathrm{kN}$

EI tiang $=\mathrm{E}$ tiang $\mathrm{x}$ Inersia tiang $(\mathrm{I})=$ $141047,590 \mathrm{kN}, \mathrm{m}$

Berat tiang $(\mathrm{w})=24 \times \mathrm{s} \times \mathrm{s}=6 \mathrm{kN} / \mathrm{m} / \mathrm{m}$

Tebal lapisan lensa pasir $(\mathrm{H})=1 \mathrm{~m}$

Dalam tiang tertanam $\mathrm{D}_{\mathrm{f}}=40 \mathrm{~m}$

Data pembebanan yang diaplikasikan pada program PLAXIS

Berikut data pembebanan untuk loading test pada tiang tunggal dengan panjang $40 \mathrm{~m}$ terdapat pada Tabel 1 .

Tabel 1. Beban pada Loading Test PLAXIS

\begin{tabular}{cc}
\hline Beban ke- & $\mathrm{P}(\mathrm{kN} / \mathrm{m})$ \\
\hline $1(25 \%)$ & 1000 \\
$2(50 \%)$ & 2000 \\
$3(75 \%)$ & 3000 \\
$4(100 \%)$ & 4000 \\
$5(125 \%)$ & 5000 \\
$6(150 \%)$ & 6000 \\
$7(200 \%)$ & 7000 \\
\hline
\end{tabular}

Beban inilah yang akan dimasukkan pada program PLAXIS yang telah diuraikan di atas.

Setelah data masukan sudah tersedia, maka proses permodelan dari perhitungan dalam program PLAXIS dapat dilanjutkan. Analisa pembebanan tiang dimodelkan seperti terlihat pada Tabel 1. Awal proses perhitungan pada PLAXIS adalah menentukan project dengan setting model plane strain yang berdasarkan tipe analisis pondasi tiang dan tipe elemen 15 nodal (15 node). Gambar 6 menunjukkan permodelan tanah dan pondasi tiang.

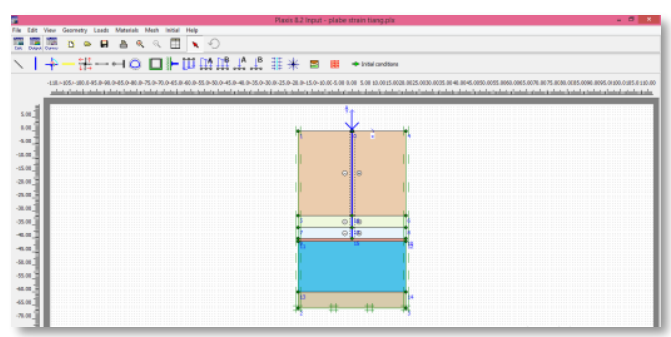

Gambar 6. Permodelan Tanah dan Pondasi Tiang pada PLAXIS

Tahapan pendefinisian material tanah dilakukan setelah tahap pemberian boundry conditions. Sebelum dilakukan meshing pada geometri, masukan data tanah sesuai dengan kondisi pada geometri yang sudah di definisikan jenis materialnya. Gambar 7 menunjukan input data untuk parameter tanah hasil uji laboratorium mapupun hasil literatur sesuai dengan kondisi tanah di lapangan.
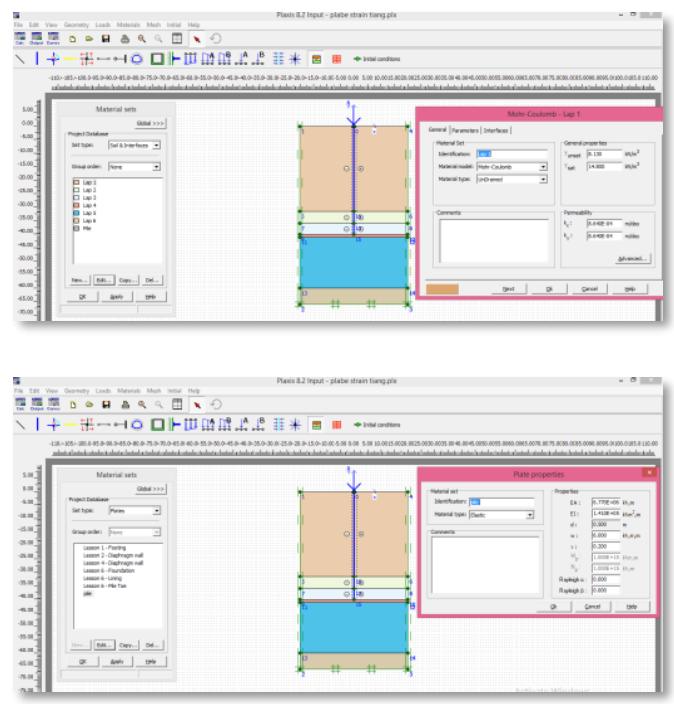

Gambar 7. Input Parameter Data Tanah dan Tiang

Meshing atau pembangunan jaring secara otomatis, dimana jaring-jaring tersebut membagi geometri menjadi beberapa elemen. Pembuatan jaring elemen berdasarkan prinsip triangulasi yang akan membentuk jaringan yang kokoh dan jaringan tersebut bentuknya tidak teratur /unstructured mesh (Gambar 8). Hal ini juga sebagai kontrol apabila ada data yang belum dimasukkan atau kurang lengkap. 
Yayuk Setiyowati dan Yulian Firmana Arifin

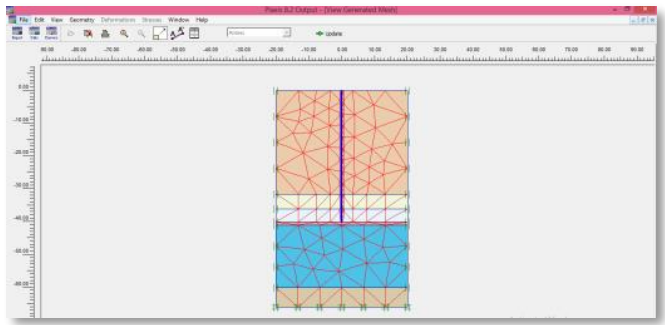

Gambar 8. Output View Generated Meshing

Initial Condition berfungsi untuk mendefinisikan keadaal awal geometri sebelum dilakukan tahap perhitungan. Keadaan awal meliputi kondisi air tanah awal (Initial ground water condition), konfigurasi awal dari geometrid dan keadaan awal tegangan efektif. Pengaktifan tegangan awal dengan cara gravity loading tidak dapat dilakukan melalui menu condition. Untuk mengetahui pori air maka digunakan water pressure generation dengan pilihan phreatic level untuk kondisi tergenang. Gambar 9 menunjukan keadaan kondisi air tanah di lapangan.

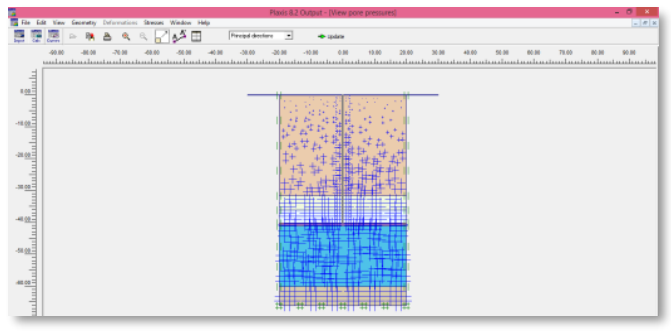

Gambar 9. Output View Pore Pressures

Pada perhitungan dengan program PLAXIS, tahap-tahap yang dilakukan pada analisa pondasi tiang tunggal di lapisan berlensa pasir adalah beban yang sudah diuraikan sebelumnya. Gambar 10 menunjukkan tahapan yang sudah diuraikan.

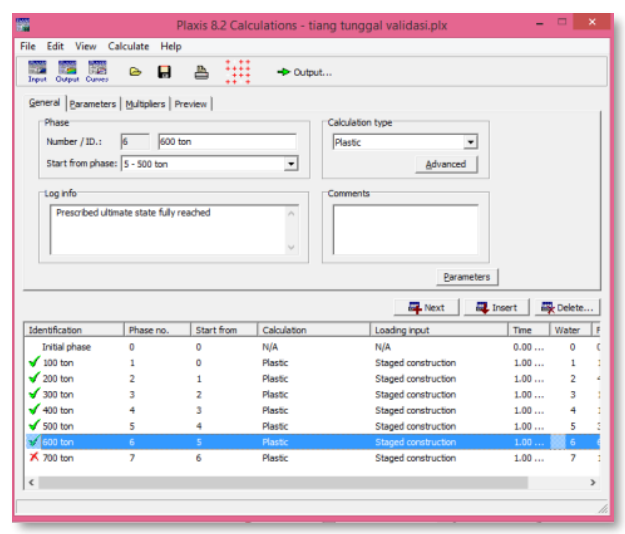

Gambar 10. Tahapan Perhitungan pada Program PLAXIS
Hasil keluaran atau output pada proram PLAXIS menghasilkan kurva dari waktu dengan penurunan. Grafik penurunan pondasi tiang hasil perhitungan PLAXIS dapat dilihat pada Gambar 11. Kemudian hasil grafik tersebut diolah sampai menghasilkan nilai daya dukung.

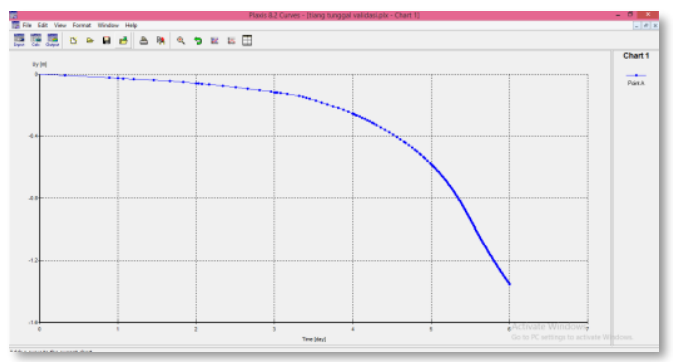

Gambar 11. Grafik Penurunan Tiang tunggal pada tanah berlensa pasir tebal $1 \mathrm{~m}$ di kedalaman $40 \mathrm{~m}$ dengan sisi tiang $0,5 \mathrm{~m}$.

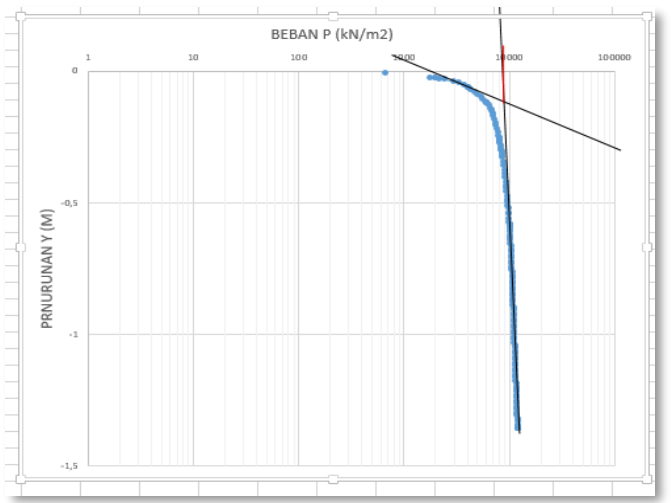

Gambar 12. Grafik Daya Dukung Tiang tunggal pada tanah berlensa pasir tebal $1 \mathrm{~m}$ di kedalaman $40 \mathrm{~m}$ dengan sisi tiang $0,5 \mathrm{~m}$.

Dari grafik hasil program didapati nilai daya dukung satu tiang pada tanah berlensa pasir setebal $1 \mathrm{~m}$ dikisaran angka $9000 \mathrm{kN} / \mathrm{m}^{2}$.

\subsection{Daya Dukung Tiang Kelompok}

Analisa daya dukung pondasi kelompok tiang dengan menganggap pada ujung pondasi (40 m) adalah lensa pasir menggunakan program PLAXIS terhadap pengaruh ketebalan lensa pasir ( $\mathrm{t}_{\text {lensa pasir }}$ ), diameter tiang $\left(\mathrm{B}_{\text {tiang }}\right)$, dan jarak tiang $\left(\mathrm{S}_{\text {tiang }}\right)$ terhadap daya dukung. Permodelan tanah dan pondasi pada Plaxis di atas lensa pasir dapat dilihat pada Gambar 13. 

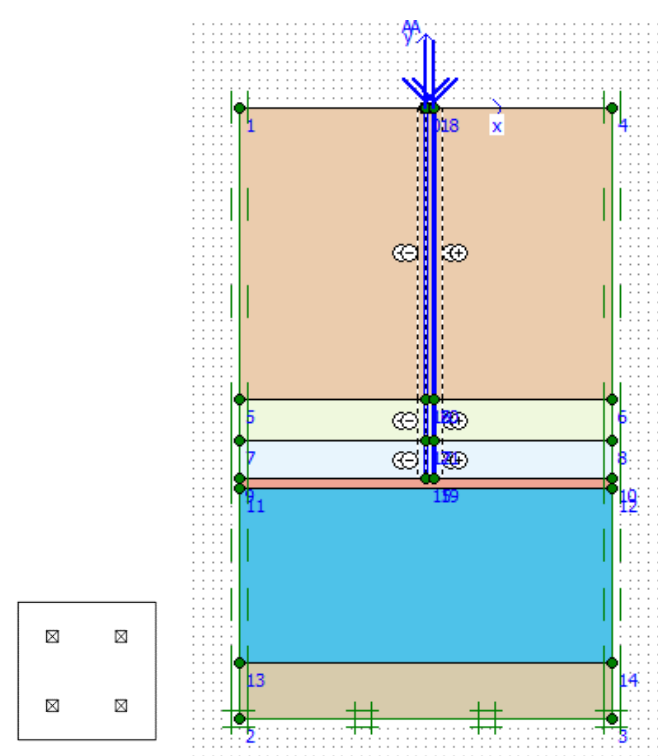

Gambar 13. Permodelan Model plane strain Group Tiang pada tanah berlensa

Parameter tiang yang diperlukan :

Sisi tiang $(B)=0,5 \mathrm{~m}$

Luas tiang $(\mathrm{A})=B \times B=0,25 \mathrm{~m}^{2}$

Inersia tiang $(\mathrm{I})=\frac{1}{12} \times b \times h^{3}=0,00213 \mathrm{~m}^{4}$

$\mathrm{K}$ tiang $(\mathrm{K})=400 \mathrm{MPa}=33,2 f^{\prime} c$

$\mathrm{E}$ tiang $(\mathrm{m})=4700 \times \sqrt{f c^{\prime}} \times 1000=$ $27081137,347 \mathrm{kN} / \mathrm{m}^{2}$

EA tiang $=\mathrm{E}$ tiang $\mathrm{x}$ Luas tiang $(\mathrm{A})=$ $6770284,337 \mathrm{kN}$

EI tiang $=\mathrm{E}$ tiang $\mathrm{x}$ Inersia tiang $(\mathrm{I})=$ $141047,590 \mathrm{kN}, \mathrm{m}$

Berat tiang $(\mathrm{w})=24 \times \mathrm{s} \mathrm{x} \mathrm{s}=6 \mathrm{kN} / \mathrm{m} / \mathrm{m}$

Tebal lapisan lensa pasir $(\mathrm{H})=1 \mathrm{~m}$

Dalam tiang tertanam $\mathrm{D}_{\mathrm{f}}=40 \mathrm{~m}$

np-row-I = 2

Jarak antar tiang $(2 \mathrm{D})=1 \mathrm{~m}$

Panjang ke belakang $(\mathrm{Lr})=\mathrm{s}+(1 \mathrm{X} 2 \mathrm{~s})=1,5 \mathrm{~m}$

Eapsp $=\operatorname{ExAx}($ np-row-i/Lr $)=9027045,782$

$(\mathrm{KN} / \mathrm{m})$

Eipsp $=\operatorname{ExIx}($ np-row-i $/ L r)=188063,454$

$(\mathrm{KNm} 2 / \mathrm{m})$

$\mathrm{Wpsp}=\mathrm{wx}(\mathrm{np}-\mathrm{row}-\mathrm{i} / \mathrm{Lr})=8(\mathrm{kN} / \mathrm{m} / \mathrm{m})$

\subsection{Pengaruh Ketebalan Lensa pasir, Diameter dan Jarak Tiang}

Perhitungan analisis dibantu dengan menggunakan PLAXIS 2D untuk mengetahui pengaruh ketebalan lensa pasir ( $\mathrm{t}_{\text {lensa }}$ pasir), diameter tiang $\left(\mathrm{s}_{\text {tiang }}\right)$, dan jarak tiang $\left(\mathrm{S}_{\text {tiang }}\right)$ terhadap daya dukung group tiang didapatkan hasil seperti penjelasan di bawah ini. Ketebalan lensa pasir yang dijadikan variabel adalah dari 1 meter sampai dengan 4 meter (Gambar 14), sedangkan diameter tiang yang dijadikan variabel adalah dari 0,3 meter sampai dengan 0,6 meter, dan jarak tiang yang yang dijadikan variabel adalah dari jarak 2D sampai dengan 5D. Panjang tiang pancang yang dijadikan penelitian adalah 40 meter yang berada di atas tanah berlensa pasir berupa pasir dengan karakteristik tertentu.

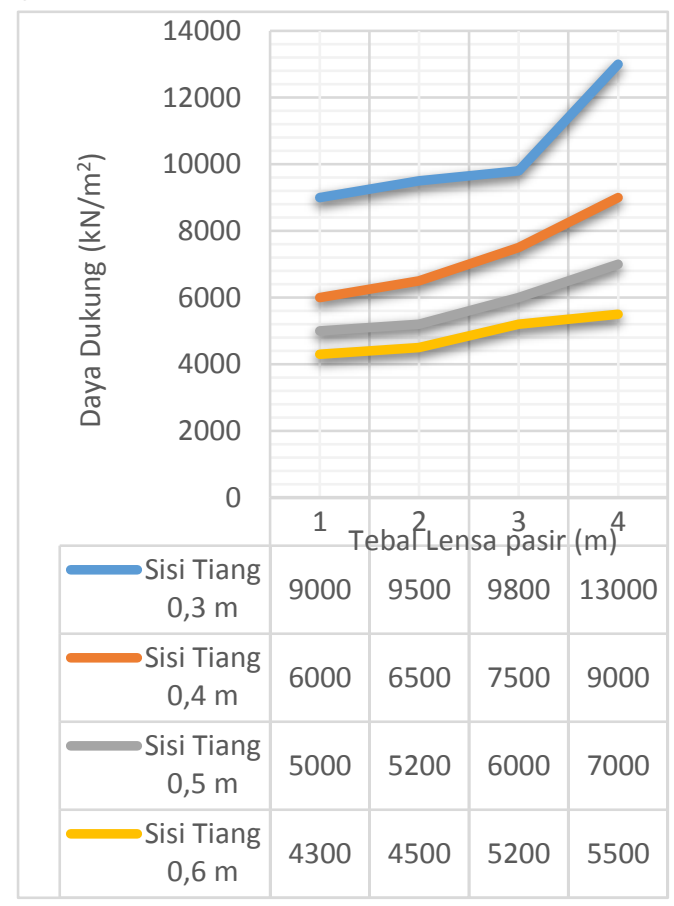

Gambar 14. Hasil daya dukung 4 Tiang dengan jarak 2D

Dari grafik di atas dapat dianalisis bahwa pada konfigurasi simetris 4 tiang dengan variasi jarak antar tiang sebesar 2D didapatkan:

1. Untuk diameter yang sama didapatkan kenaikan daya dukung berbanding lurus dengan kenaikan ketebalan lensa pasir. Seperti hasil yang ditunjukkan pada sisi tiang 0,4 meter menghasilkan nilai daya dukung sebesar $6000 \mathrm{kN} / \mathrm{m}^{2}$ pada ketebalan lensa pasir 1 meter, dan menghasilkan daya dukung $6500 \mathrm{kN} / \mathrm{m}^{2}$ pada ketebalan lensa pasir 2 meter, dan pada ketebalan lensa pasir 3 meter dan 4 meter menghasilkan daya dukung masing-masing sebesar 7500 $\mathrm{kN} / \mathrm{m}^{2}$ dan $9000 \mathrm{kN} / \mathrm{m}^{2}$. Kenaikan daya dukung tersebut dikarenakan karakteristik kuat geser dari lapisan lensa pasir yang memberikan pengaruh besar.

2. Untuk ketebalan lensa pasir yang sama maka didapatkan penurunan daya dukung 
Yayuk Setiyowati dan Yulian Firmana Arifin

berbanding lurus dengan kenaikan diameter tiang. Seperti hasil yang ditunjukkan pada ketebalan lensa pasir di 2 meter menghasilkan nilai daya dukung sebesar $9500 \mathrm{kN} / \mathrm{m}^{2}$ pada sisi tiang 0,3 meter, dan menghasilkan daya dukung $6500 \mathrm{kN} / \mathrm{m}^{2}$ pada sisi tiang 0,4 meter, dan pada sisi tiang 0,5 meter dan 0,6 meter menghasilkan daya dukung masing-masing sebesar 5200 $\mathrm{kN} / \mathrm{m}^{2}$ dan $4500 \mathrm{kN} / \mathrm{m}^{2}$. Penurunan daya dukung tersebut dikarenakan area tekan pada lapisan lensa pasir memberikan pengaruh yang signifikan.

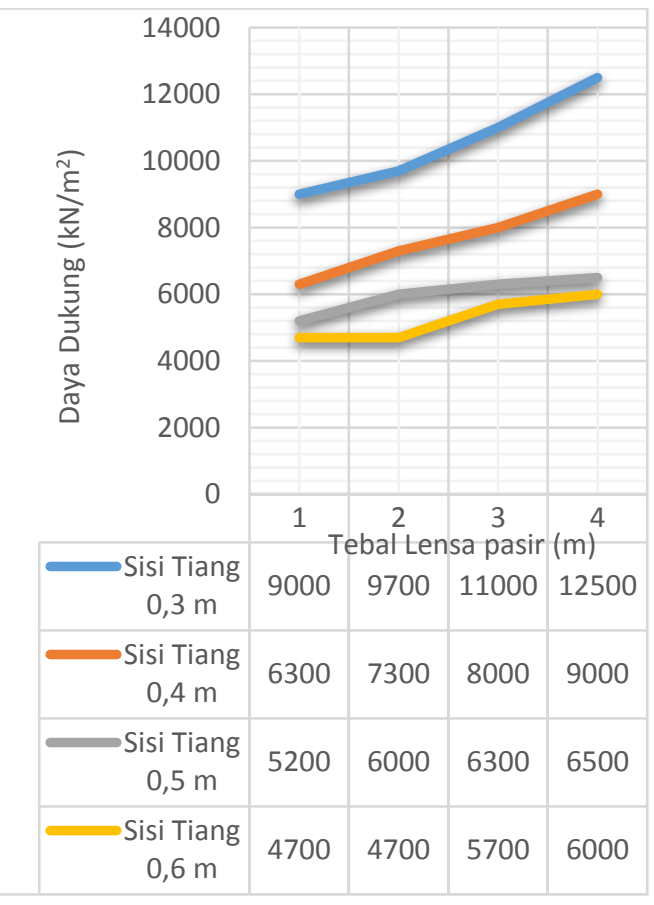

Gambar 15. Hasil daya dukung 4 Tiang dengan jarak 3D

Dari Gambar 15 di atas dapat dianalisis bahwa pada konfigurasi simetris 4 tiang dengan variasi jarak antar tiang sebesar 3D didapatkan:

1. Untuk diameter yang sama didapatkan kenaikan daya dukung berbanding lurus dengan kenaikan ketebalan lensa pasir. Seperti hasil yang ditunjukkan pada sisi tiang 0,4 meter menghasilkan nilai daya dukung sebesar $6300 \mathrm{kN} / \mathrm{m}^{2}$ pada ketebalan lensa pasir 1 meter, dan menghasilkan daya dukung $7300 \mathrm{kN} / \mathrm{m}^{2}$ pada ketebalan lensa pasir 2 meter, dan pada ketebalan lensa pasir 3 meter dan 4 meter menghasilkan daya dukung masing-masing sebesar 8000 $\mathrm{kN} / \mathrm{m}^{2}$ dan $9000 \mathrm{kN} / \mathrm{m}^{2}$. Kenaikan daya dukung tersebut dikarenakan karakteristik kuat geser dari lapisan lensa pasir yang memberikan pengaruh besar.

2. Untuk ketebalan lensa pasir yang sama maka didapatkan penurunan daya dukung berbanding lurus dengan kenaikan diameter tiang. Seperti hasil yang ditunjukkan pada ketebalan lensa pasir di 2 meter menghasilkan nilai daya dukung sebesar $9700 \mathrm{kN} / \mathrm{m}^{2}$ pada sisi tiang 0,3 meter, dan menghasilkan daya dukung $7300 \mathrm{kN} / \mathrm{m}^{2}$ pada sisi tiang 0,4 meter, dan pada sisi tiang 0,5 meter dan 0,6 meter menghasilkan daya dukung masing-masing sebesar 6000 $\mathrm{kN} / \mathrm{m}^{2}$ dan $4700 \mathrm{kN} / \mathrm{m}^{2}$. Penurunan daya dukung tersebut dikarenakan area tekan pada lapisan lensa pasir memberikan pengaruh yang signifikan.

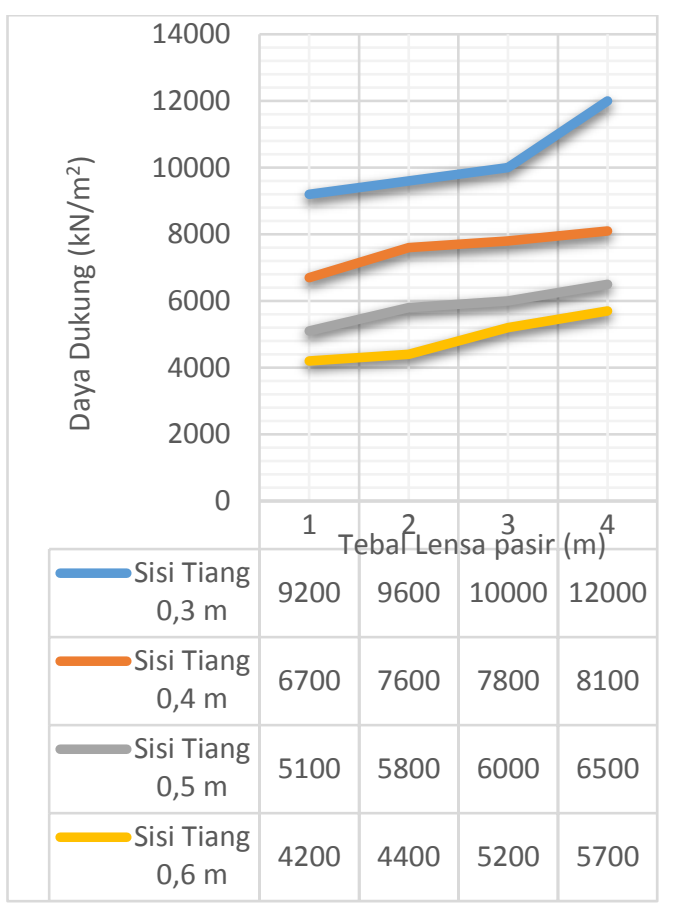

Gambar 16. Hasil daya dukung 4 Tiang dengan jarak 4D

Dari Gambar 16 di atas dapat dianalisis bahwa pada konfigurasi simetris 4 tiang dengan variasi jarak antar tiang sebesar 4D didapatkan:

1. Untuk diameter yang sama didapatkan kenaikan daya dukung berbanding lurus dengan kenaikan ketebalan lensa pasir. Seperti hasil yang ditunjukkan pada sisi tiang 0,4 meter menghasilkan nilai daya dukung sebesar $6700 \mathrm{kN} / \mathrm{m}^{2}$ pada ketebalan lensa pasir 1 meter, dan menghasilkan daya dukung $7600 \mathrm{kN} / \mathrm{m}^{2}$ pada ketebalan lensa pasir 2 meter, dan pada ketebalan lensa 
Yayuk Setiyowati dan Yulian Firmana Arifin

pasir 3 meter dan 4 meter menghasilkan daya dukung masing-masing sebesar 7800 $\mathrm{kN} / \mathrm{m} 2$ dan $8100 \mathrm{kN} / \mathrm{m} 2$. Kenaikan daya dukung tersebut dikarenakan karakteristik kuat geser dari lapisan lensa pasir yang memberikan pengaruh besar.

2. Untuk ketebalan lensa pasir yang sama maka didapatkan penurunan daya dukung berbanding lurus dengan kenaikan diameter tiang. Seperti hasil yang ditunjukkan pada ketebalan lensa pasir di 2 meter menghasilkan nilai daya dukung sebesar $9600 \mathrm{kN} / \mathrm{m} 2$ pada sisi tiang 0,3 meter, dan menghasilkan daya dukung $7600 \mathrm{kN} / \mathrm{m} 2$ pada sisi tiang 0,4 meter, dan pada sisi tiang 0,5 meter dan 0,6 meter menghasilkan daya dukung masing-masing sebesar $5800 \mathrm{kN} / \mathrm{m} 2$ dan $4400 \mathrm{kN} / \mathrm{m} 2$. Penurunan daya dukung tersebut dikarenakan area tekan pada lapisan lensa pasir memberikan pengaruh yang signifikan.

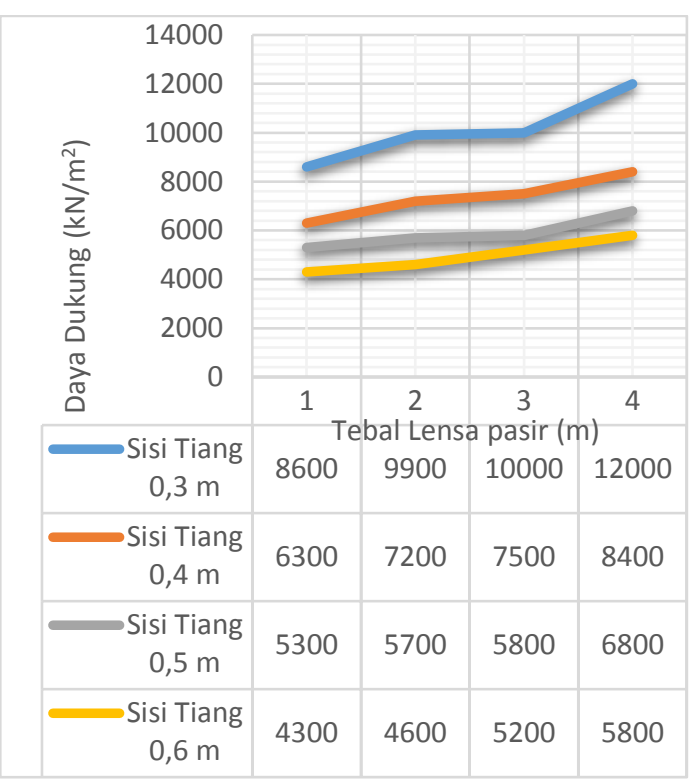

Gambar 17. Hasil daya dukung 4 Tiang dengan jarak 5D

Dari Gambar 17 di atas dapat dianalisis bahwa pada konfigurasi simetris 4 tiang dengan variasi jarak antar tiang sebesar 5D didapatkan :

1. Untuk diameter yang sama didapatkan kenaikan daya dukung berbanding lurus dengan kenaikan ketebalan lensa pasir. Seperti hasil yang ditunjukkan pada sisi tiang 0,4 meter menghasilkan nilai daya dukung sebesar $6300 \mathrm{kN} / \mathrm{m} 2$ pada ketebalan lensa pasir 1 meter, dan menghasilkan daya dukung $7200 \mathrm{kN} / \mathrm{m} 2$ pada ketebalan lensa pasir 2 meter, dan pada ketebalan lensa pasir 3 meter dan 4 meter menghasilkan daya dukung masing-masing sebesar $7500 \mathrm{kN} / \mathrm{m}^{2}$ dan $8400 \mathrm{kN} / \mathrm{m}^{2}$. Kenaikan daya dukung tersebut dikarenakan karakteristik kuat geser dari lapisan lensa pasir yang memberikan pengaruh besar.

2. Untuk ketebalan lensa pasir yang sama maka didapatkan penurunan daya dukung berbanding lurus dengan kenaikan diameter tiang. Seperti hasil yang ditunjukkan pada ketebalan lensa pasir di 2 meter menghasilkan nilai daya dukung sebesar $9900 \mathrm{kN} / \mathrm{m}^{2}$ pada sisi tiang 0,3 meter, dan menghasilkan daya dukung $7200 \mathrm{kN} / \mathrm{m}^{2}$ pada sisi tiang 0,4 meter, dan pada sisi tiang 0,5 meter dan 0,6 meter menghasilkan daya dukung masing-masing sebesar $5700 \mathrm{kN} / \mathrm{m}^{2}$ dan $4600 \mathrm{kN} / \mathrm{m}^{2}$. Penurunan daya dukung tersebut dikarenakan area tekan pada lapisan lensa pasir memberikan pengaruh yang signifikan.

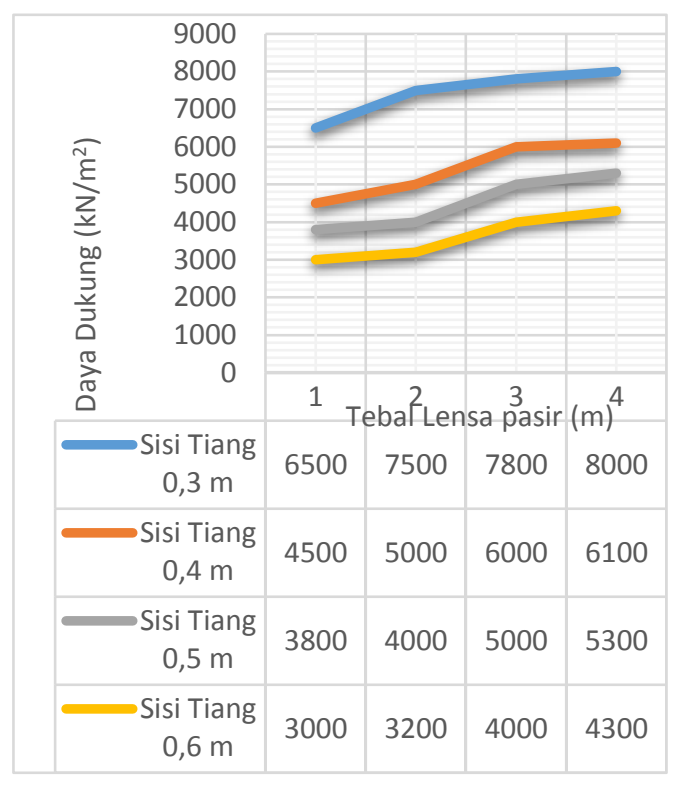

Gambar 18. Hasil daya dukung 9 Tiang dengan jarak 2D

Dari Gambar 18 di atas dapat dianalisis bahwa pada konfigurasi simetris 9 tiang dengan variasi jarak antar tiang sebesar 2D didapatkan

1. Untuk diameter yang sama didapatkan kenaikan daya dukung berbanding lurus dengan kenaikan ketebalan lensa pasir. Seperti hasil yang ditunjukkan pada sisi tiang 0,4 meter menghasilkan nilai daya dukung sebesar $4500 \mathrm{kN} / \mathrm{m}^{2}$ pada ketebalan lensa pasir 1 meter, dan menghasilkan daya 
Yayuk Setiyowati dan Yulian Firmana Arifin

dukung $5000 \mathrm{kN} / \mathrm{m}^{2}$ pada ketebalan lensa pasir 2 meter, dan pada ketebalan lensa pasir 3 meter dan 4 meter menghasilkan daya dukung masing-masing sebesar $6000 \mathrm{kN} / \mathrm{m}^{2}$ dan $6100 \mathrm{kN} / \mathrm{m}^{2}$. Kenaikan daya dukung tersebut dikarenakan karakteristik kuat geser dari lapisan lensa pasir yang memberikan pengaruh besar.

2. Untuk ketebalan lensa pasir yang sama maka didapatkan penurunan daya dukung berbanding lurus dengan kenaikan diameter tiang. Seperti hasil yang ditunjukkan pada ketebalan lensa pasir di 2 meter menghasilkan nilai daya dukung sebesar $7500 \mathrm{kN} / \mathrm{m}^{2}$ pada sisi tiang 0,3 meter, dan menghasilkan daya dukung $5000 \mathrm{kN} / \mathrm{m}^{2}$ pada sisi tiang 0,4 meter, dan pada sisi tiang 0,5 meter dan 0,6 meter menghasilkan daya dukung masing-masing sebesar $4000 \mathrm{kN} / \mathrm{m}^{2}$ dan $3200 \mathrm{kN} / \mathrm{m}^{2}$. Penurunan daya dukung tersebut dikarenakan area tekan pada lapisan lensa pasir memberikan pengaruh yang signifikan.

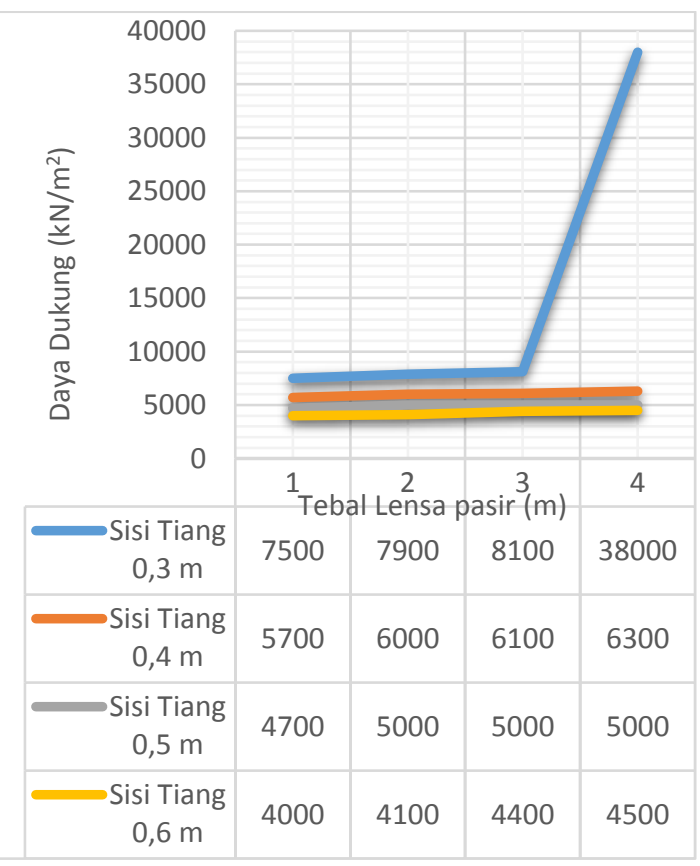

Gambar 19. Hasil daya dukung 9 Tiang dengan jarak 3D

Dari Gambar 19 di atas dapat dianalisis bahwa pada konfigurasi simetris 9 tiang dengan variasi jarak antar tiang sebesar 3D didapatkan:

1. Untuk diameter yang sama didapatkan kenaikan daya dukung berbanding lurus dengan kenaikan ketebalan lensa pasir. Seperti hasil yang ditunjukkan pada sisi tiang 0,4 meter menghasilkan nilai daya dukung sebesar $5700 \mathrm{kN} / \mathrm{m}^{2}$ pada ketebalan lensa pasir 1 meter, dan menghasilkan daya dukung $6000 \mathrm{kN} / \mathrm{m}^{2}$ pada ketebalan lensa pasir 2 meter, dan pada ketebalan lensa pasir 3 meter dan 4 meter menghasilkan daya dukung masing-masing sebesar $6100 \mathrm{kN} / \mathrm{m}^{2}$ dan $6300 \mathrm{kN} / \mathrm{m}^{2}$. Kenaikan daya dukung tersebut dikarenakan karakteristik kuat geser dari lapisan lensa pasir yang memberikan pengaruh besar.

2. Untuk ketebalan lensa pasir yang sama maka didapatkan penurunan daya dukung berbanding lurus dengan kenaikan diameter tiang. Seperti hasil yang ditunjukkan pada ketebalan lensa pasir di 2 meter menghasilkan nilai daya dukung sebesar $7900 \mathrm{kN} / \mathrm{m}^{2}$ pada sisi tiang 0,3 meter, dan menghasilkan daya dukung $6000 \mathrm{kN} / \mathrm{m}^{2}$ pada sisi tiang 0,4 meter, dan pada sisi tiang 0,5 meter dan 0,6 meter menghasilkan daya dukung masing-masing sebesar $5000 \mathrm{kN} / \mathrm{m}^{2}$ dan $4100 \mathrm{kN} / \mathrm{m}^{2}$. Penurunan daya dukung tersebut dikarenakan area tekan pada lapisan lensa pasir memberikan pengaruh yang signifikan.

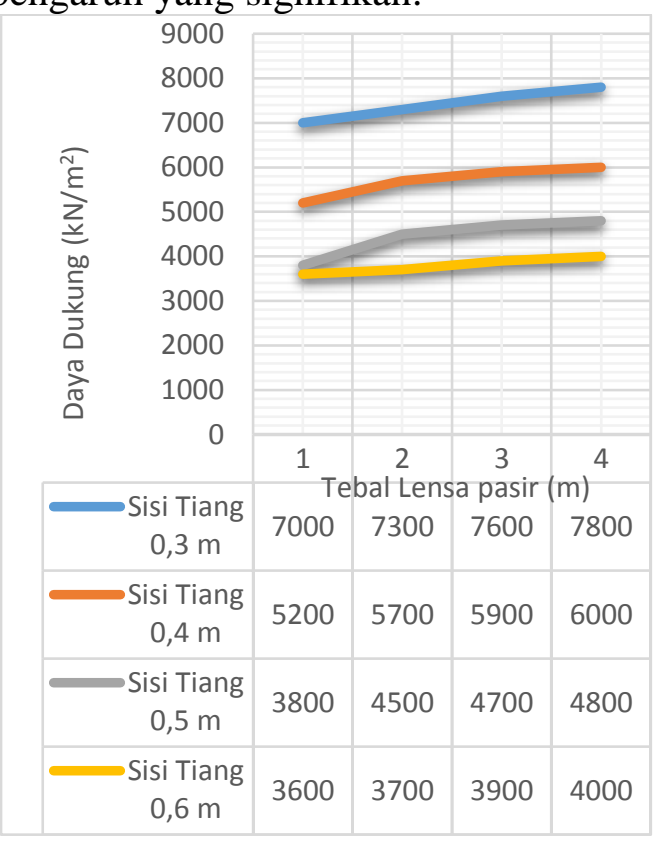

Gambar 20. Hasil daya dukung 9 Tiang dengan jarak 4D

Dari Gambar 20 di atas dapat dianalisis bahwa pada konfigurasi simetris 9 tiang dengan variasi jarak antar tiang sebesar 4D didapatkan

1. Untuk diameter yang sama didapatkan kenaikan daya dukung berbanding lurus 
Yayuk Setiyowati dan Yulian Firmana Arifin

dengan kenaikan ketebalan lensa pasir. Seperti hasil yang ditunjukkan pada sisi tiang 0,4 meter menghasilkan nilai daya dukung sebesar $5200 \mathrm{kN} / \mathrm{m}^{2}$ pada ketebalan lensa pasir 1 meter, dan menghasilkan daya dukung $5700 \mathrm{kN} / \mathrm{m}^{2}$ pada ketebalan lensa pasir 2 meter, dan pada ketebalan lensa pasir 3 meter dan 4 meter menghasilkan daya dukung masing-masing sebesar $5900 \mathrm{kN} / \mathrm{m}^{2}$ dan $6000 \mathrm{kN} / \mathrm{m}^{2}$. Kenaikan daya dukung tersebut dikarenakan karakteristik kuat geser dari lapisan lensa pasir yang memberikan pengaruh besar.

2. Untuk ketebalan lensa pasir yang sama maka didapatkan penurunan daya dukung berbanding lurus dengan kenaikan diameter tiang. Seperti hasil yang ditunjukkan pada ketebalan lensa pasir di 2 meter menghasilkan nilai daya dukung sebesar $7300 \mathrm{kN} / \mathrm{m}^{2}$ pada sisi tiang 0,3 meter, dan menghasilkan daya dukung $5700 \mathrm{kN} / \mathrm{m}^{2}$ pada sisi tiang 0,4 meter, dan pada sisi tiang 0,5 meter dan 0,6 meter menghasilkan daya dukung masing-masing sebesar $4500 \mathrm{kN} / \mathrm{m}^{2}$ dan $3700 \mathrm{kN} / \mathrm{m}^{2}$. Penurunan daya dukung tersebut dikarenakan area tekan pada lapisan lensa pasir memberikan pengaruh yang signifikan.

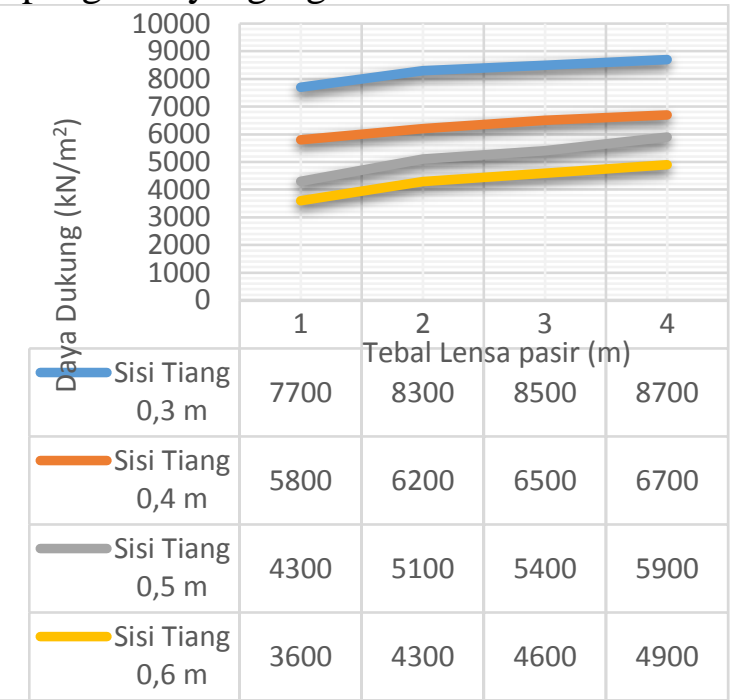

Gambar 21. Hasil daya dukung 9 Tiang dengan jarak 5D

Dari Gambar 21 di atas dapat dianalisis bahwa pada konfigurasi simetris 9 tiang dengan variasi jarak antar tiang sebesar 5D didapatkan:

1. Untuk diameter yang sama didapatkan kenaikan daya dukung berbanding lurus dengan kenaikan ketebalan lensa pasir. Seperti hasil yang ditunjukkan pada sisi tiang 0,4 meter menghasilkan nilai daya dukung sebesar $5800 \mathrm{kN} / \mathrm{m}^{2}$ pada ketebalan lensa pasir 1 meter, dan menghasilkan daya dukung $6200 \mathrm{kN} / \mathrm{m}^{2}$ pada ketebalan lensa pasir 2 meter, dan pada ketebalan lensa pasir 3 meter dan 4 meter menghasilkan daya dukung masing-masing sebesar $6500 \mathrm{kN} / \mathrm{m}^{2}$ dan $6700 \mathrm{kN} / \mathrm{m}^{2}$. Kenaikan daya dukung tersebut dikarenakan karakteristik kuat geser dari lapisan lensa pasir yang memberikan pengaruh besar.

2. Untuk ketebalan lensa pasir yang sama maka didapatkan penurunan daya dukung berbanding lurus dengan kenaikan diameter tiang. Seperti hasil yang ditunjukkan pada ketebalan lensa pasir di 2 meter menghasilkan nilai daya dukung sebesar $8300 \mathrm{kN} / \mathrm{m}^{2}$ pada sisi tiang 0,3 meter, dan menghasilkan daya dukung $6200 \mathrm{kN} / \mathrm{m}^{2}$ pada sisi tiang 0,4 meter, dan pada sisi tiang 0,5 meter dan 0,6 meter menghasilkan daya dukung masing-masing sebesar $5100 \mathrm{kN} / \mathrm{m}^{2}$ dan $4300 \mathrm{kN} / \mathrm{m}^{2}$. Penurunan daya dukung tersebut dikarenakan area tekan pada lapisan lensa pasir memberikan pengaruh yang signifikan.

Dari semua hasil daya dukung yang didapatkan melalui program PLAXIS 2D, maka penulis rangkum menjadi summary agar dapat terlihat secara jelas perubahan hasil daya dukung yang terjadi pada setiap perubahan variabel ketebalan lensa pasir ( $t_{\text {lensa pasir), }}$, diameter tiang ( $\left.\mathrm{s}_{\text {tiang }}\right)$, dan jarak tiang $\left(\mathrm{S}_{\text {tiang }}\right)$, seperti yang terpampang pada tabel di bawah ini.

Dari Tabel 2 dapat ditarik kesimpulan bahwa pada konfigurasi 4 tiang, jarak antar tiang yang paling berperan dalam memberikan daya dukung adalah di jarak antar tiang 3D, dimana hasil daya dukung yang dihasilkan pada jarak ini lebih tinggi. Sedangkan hasil daya dukung pada jarak antar tiang 4D dan 5D mengalami penurunan, dimungkinkan karena cara penarikan garis pada grafik daya dukung dengan penurunan.

Dari Tabel 3 dapat ditarik kesimpulan bahwa pada konfigurasi 9 tiang, hasil didapatkan hamper serupa dengan hasil yang didapatkan pada konfigurasi 4 tiang. Dimana 
Yayuk Setiyowati dan Yulian Firmana Arifin

jarak antar tiang yang paling berperan dalam memberikan daya dukung adalah di jarak antar tiang 3D dan 5D, dimana hasil daya dukung yang dihasilkan pada jarak ini lebih tinggi.Sedangkan hasil daya dukung pada jarak antar tiang 4D mengalami penurunan, dimungkinkan karena cara penarikan garis pada grafik daya dukung dengan penurunan.

Dari Tabel 2 dan Tabel 3 juga dapat ditarik kesimpulan bahwa konfigurasi tiang yang lebih baik untuk diterapkan pada tanah berlensa pasir adalah konfigurasi 4 tiang simetris, dimana hasil daya dukung yang dihasilkan pada konfigurasi ini lebih tinggi dibandingkan konfigurasi 9 tiang simetris.

Tabel 2. Summary hasil daya dukung dengan konfigurasi 4 tiang simetris

\begin{tabular}{|c|c|c|c|c|c|}
\hline \multirow{2}{*}{$\begin{array}{c}\text { Sisi } \\
\text { Tia } \\
\text { ng } \\
\text { (m) }\end{array}$} & \multirow{2}{*}{$\begin{array}{l}\text { Jarak } \\
\text { Antar } \\
\text { Tiang }\end{array}$} & \multicolumn{4}{|c|}{ Tebal Lensa (m) } \\
\hline & & 1 & 2 & 3 & 4 \\
\hline \multirow{4}{*}{0,3} & $2 \mathrm{D}$ & 9000 & 9500 & 9800 & 13000 \\
\hline & $3 \mathrm{D}$ & 9000 & 9700 & 11000 & 12500 \\
\hline & ח & חסרם & 0600 & 10000 & חمח12 \\
\hline & $5 \mathrm{D}$ & 8600 & 9900 & 10000 & 12000 \\
\hline \multirow{5}{*}{0,4} & $2 \mathrm{D}$ & 6000 & 6500 & 7500 & 9000 \\
\hline & $3 \mathrm{D}$ & 6300 & 7300 & 8000 & 9000 \\
\hline & & & & & \\
\hline & $4 \mathrm{D}$ & 6700 & 7600 & 7800 & 8100 \\
\hline & $5 D$ & 6300 & 7200 & 7500 & 8400 \\
\hline \multirow{5}{*}{0,5} & $2 \mathrm{D}$ & 5000 & 5200 & 6000 & 7000 \\
\hline & $3 \mathrm{D}$ & 5200 & 6000 & 6300 & 6500 \\
\hline & & & & & \\
\hline & 4D & 5100 & 5800 & 6000 & 6500 \\
\hline & $5 D$ & 5300 & 5700 & 5800 & 6800 \\
\hline \multirow{5}{*}{0,6} & $2 \mathrm{D}$ & 4300 & 4500 & 5200 & 5500 \\
\hline & $3 D$ & 4700 & 4700 & 5700 & 6000 \\
\hline & & & & & \\
\hline & 4D & 4200 & 4400 & 5200 & 5700 \\
\hline & $5 D$ & 4300 & 4600 & 5200 & 5800 \\
\hline
\end{tabular}

Tabel 3. Summary hasil daya dukung dengan konfigurasi 9 tiang simetris

\begin{tabular}{|c|c|c|c|c|c|}
\hline \multirow{2}{*}{$\begin{array}{l}\text { Sisi } \\
\text { Tia } \\
\text { ng } \\
\text { (m) }\end{array}$} & \multirow{2}{*}{$\begin{array}{l}\text { Jarak } \\
\text { Antar } \\
\text { Tiang }\end{array}$} & \multicolumn{4}{|c|}{ Tebal Lensa (m) } \\
\hline & & 1 & 2 & 3 & 4 \\
\hline \multirow{4}{*}{0,3} & $2 \mathrm{D}$ & 6500 & 7500 & 7800 & 8000 \\
\hline & $3 D$ & 7500 & 7900 & 8100 & 38000 \\
\hline & 4D & 7000 & 7300 & 7600 & 7800 \\
\hline & $5 \mathrm{D}$ & 7700 & 8300 & 8500 & 8700 \\
\hline \multirow{4}{*}{0,4} & 2D & 4500 & 5000 & 6000 & 6100 \\
\hline & $3 D$ & 5700 & 6000 & 6100 & 6300 \\
\hline & $4 \mathrm{D}$ & 5200 & 5700 & 5900 & 6000 \\
\hline & $5 \mathrm{D}$ & 5800 & 6200 & 6500 & 6700 \\
\hline \multirow{5}{*}{0,5} & $2 \mathrm{D}$ & 3800 & 4000 & 5000 & 5300 \\
\hline & $3 D$ & 4700 & 5000 & 5000 & 5000 \\
\hline & & & & & \\
\hline & 4D & 3800 & 4500 & 4700 & 4800 \\
\hline & $5 \mathrm{D}$ & 4300 & 5100 & 5400 & 5900 \\
\hline \multirow{5}{*}{0,6} & $2 \mathrm{D}$ & 3000 & 3200 & 4000 & 4300 \\
\hline & $3 D$ & 4000 & 4100 & 4400 & 4500 \\
\hline & & & & & \\
\hline & $4 \mathrm{D}$ & 3600 & 3700 & 3900 & 4000 \\
\hline & $5 D$ & 3600 & 4300 & 4600 & 4900 \\
\hline
\end{tabular}

\section{KESIMPULAN}

Berdasarkan hasil analisis, maka dapat diambil kesimpulan sebagai berikut:

1. Daya dukung tiang tunggal pada lapisan lensa pasir hasil PLAXIS lebih kecil dari hasil perhitungan daya dukung secara teoritis.

2. Daya dukung kelompok tiang pada lapisan lensa pasir hasil PLAXIS.

a. Untuk diameter yang sama didapatkan kenaikan daya dukung berbanding lurus dengan kenaikan ketebalan lensa pasir. Kenaikan daya dukung tersebut dikarenakan karakteristik kuat geser dari lapisan lensa pasir yang memberikan pengaruh besar dan bahwa lensa yang 
Yayuk Setiyowati dan Yulian Firmana Arifin

memiliki tebal lebih dari 4 meter sudah memiliki karakteristik seperti tanah keras.

b. Untuk ketebalan lensa pasir yang sama maka didapatkan penurunan daya dukung berbanding lurus dengan kenaikan diameter tiang. Penurunan daya dukung tersebut dikarenakan area tekan pada lapisan lensa pasir memberikan pengaruh yang signifikan.

c. Pada konfigurasi 4 tiang, jarak antar tiang yang paling berperan dalam memberikan daya dukung adalah di jarak antar tiang 3D, dimana hasil daya dukung yang dihasilkan pada jarak ini lebih tinggi. Sedangkan hasil daya dukung pada jarak antar tiang 4D dan 5D mengalami penurunan, dimungkinkan karena cara penarikan garis pada grafik daya dukung dengan penurunan.

d. Pada konfigurasi 9 tiang, hasil didapatkan hampir serupa dengan hasil yang didapatkan pada konfigurasi 4 tiang. Dimana jarak antar tiang yang paling berperan dalam memberikan daya dukung adalah di jarak antar tiang 3D dan 5D, dimana hasil daya dukung yang dihasilkan pada jarak ini lebih tinggi.Sedangkan hasil daya dukung pada jarak antar tiang 4D mengalami penurunan, dimungkinkan karena cara penarikan garis pada grafik daya dukung dengan penurunan.

e. Konfigurasi tiang yang lebih baik untuk diterapkan pada tanah berlensa pasir adalah konfigurasi 4 tiang simetris, dimana hasil daya dukung yang dihasilkan pada konfigurasi ini lebih tinggi dibandingkan konfigurasi 9 tiang simetris.

\section{DAFTAR PUSTAKA}

Andre Ryltenius. 2011. FEM Modelling of piled raft foundations in two and three dimensions. Master Disertasi, Geotechnical Eng., Univ. LUND Sweden.

Anonim ${ }^{1}$. Peta Geologi Kalimantan (1994) (diakses 1 Oktober 2017)

Hardiyatmo, H.C., 1996, Teknik Pondasi 1. PT. Gramedia Pustaka Utama. Jakarta.
Hardiyatmo, H. C., 2002, Teknik Pondasi 2, Edisi Kedua, Beta Offset. Yogyakarta

Joel Algulin, Bjorn Pedersen. 2014. Modelling of a piled raft foundation as a plane strain model in PLAXIS 2D A geotechnical case study of Nordstaden 8:27. Thesis, Dept. Civil and Environmental Eng., Univ. Chalmers Sweden.

Sosarodarsono, S. Dan Nakazawa, K. 1983. Mekanika Tanah dan Teknik Pondasi. PT. Pradnya Paramita. Jakarta.

Tomlinson, MJ. 2001. Foundation Design and Contruction, $7^{\text {th }}$ Edition. Peardon Education. England.

Wesley, L.D. 1997. Mekanika Tanah. Badan Penerbit Pekerjaan Umum. 